\title{
Comparative Effectiveness of Virtual Field Trip and Real Field Trip on Students' Academic Performance in Social Studies in Osun State Secondary Schools
}

\author{
Dr. A. J. Obadiora
}

Department of Arts and Social Science Education, Faculty of Education, Obafemi Awololowo University lle-Ife

\author{
Doi:10.5901/mjss.2016.v7n1p467
}

\section{Abstract}

This study compared the effectiveness of virtual field trip and real field trip on students' knowledge and retention ability in Social Studies in Osun State secondary schools. The sample consist of 127 JSS I students. Two public schools were randomly selected for the study. From each of the two schools, one intact JSS1 class was randomly assigned to either virtual field trip or real field trip group. One instrument was used for this study. Data collected were subjected to analysis of covariance (ANCOVA). The result showed that there is a significant difference in the effectiveness of virtual field trip and real field trip on students' knowledge in Social Studies ( $F=433.108)$ in favour of virtual field trip at $p=0.000$. The results also indicated significant effectiveness of virtual field trip and real field trip on students retention ability $(F=470.020)$ in favour of real field trip at $p=0.000$. Based on the findings of this study it was concluded that virtual field trip strategy is more effective in enhancing students learning in Social Studies than the real field trip strategy. Whereas real field trip strategy can help students to retain knowledge better and longer than virtual field trip strategy.

Keywords: Virtual Field Trip, Real Field Trip, Academic Performance

\section{Introduction}

Learning can take place everywhere, not only in the classroom or in the school environment. It could happen on the street, in the market place, in the place of worship, in the waters, in the space etc. This is not just talking about a particular type of education, it could be any type, formal, informal or non-formal education, it is all about learning generally. Oblinger, (2006) supports this assertion, he agrees that human beings wherever they are have the capacity to learn through their experiences and reflections. The fact that everything and every event of life provide information for education, justify teacher's effort to take student outside the four wall of the classroom for effective learning. This could be better explained in the values that educators attached to the relevant of field trip instructional strategy in the teaching and learning process. The traditional practice of field trip as an instructional strategy takes the students outside of the school environment. Thus field trip becomes a form of community contact instructional strategy adopted in the formal school system for the purpose of education.

Krepel and Durrall (1981) describe field trip as a school or class trip with an educational intent, in which students interact with the setting, displays, and exhibits to gain an experiential connection to the ideas, concepts, and subject matter. According to Oloyede, Ajibade and Bamidele (2006) field trip is the act of taking pupils out of the classroom into the community for the purpose of learning. Nabors, Edwards and Murray (2009) share the same view with the aforementioned authors that field trip is a type of experiential learning that gets children away from the traditional classroom setting and into a new mode of learning. Tal and Morag (2009) opinion is not differ from that of other scholars, they describe field trips as student experiences outside of the classroom at interactive locations designed for educational purposes. In view of this, the general perception of people as regard field trip is any teaching and learning process carried out by a group of people outside of the classroom environment.

Scholars have said many things about the values of field trip especially for the effective teaching of Social Studies. The main reason of organising field trip for the learners in Social Studies class is to go out and observe for the purpose of education. On field trips learners sharpen their skills of observation and perception by utilizing all their senses (Nabors, Edwards and Murray 2009). Based on this Shakil, Faizi and Hafeez (2011) submit that field trip enhance learners mental development through observation. Also, one of the fundamental values of field trip is the fact that it provides real experiences. It gives the learners opportunity to interact with what they are learning, learners are able to see it, participate in it physically (Shakil, Faizi \& Hafeez 2011) and as a result develop strong retention ability. Field trip does not just provide real experiences but real experiences that relate to all content areas in Social Studies (Nabors, Edwards \& 
Murray 2009, Myers and Jones 2009). This is possible because field trip can be organised to take learners to different places so as to obtain first hand information on different subject matter as well as different aspect of Social Studies curriculum content. A field trip is a chance to do something new and different in a new environment, breaking away from the humdrum of the school routine. This can reinvigorate children and breathe life into lesson plans (Fuller, 2012).

When children take a field trip to visit the local environment, they begin to understand, in a very concrete way, the value of community resources. Field trip allows children to participate in activities in which they become community advocates and thus fulfilling their civic obligations. Field trip provides living laboratories where children acquire knowledge outside the realm of the regular classroom (Nabors, Edwards \& Murray 2009). The fact that everyknowledge acquired through any form of education should be applied in a particular situation makes field trip a more valuable instructional strategy. Field trips teach students how to apply knowledge to their daily lives. Since students can see workers in their workplace, see how the real world functions instead of only listening to it described in classroom lectures and reading about it in textbooks (Greenhalgh, 2012) field trip trains learners how to go about their social responsibilities and heightened learners' interest in the career of their choice (Heath, 2012).

Field trip is an important tool in Social Studies to promote learners interaction with others. During the field trip it is possible that teachers divide learners into groups and assign them team tasks. When groups work together throughout a field trip, it improves learner communication with peers. Educational trips offer interaction and cooperation among students, teachers, other administrative staff and representatives at the field trip destination who offer guided tours and conduct question-and-answer sessions. In view of this learners expand their educational networks through interacting with others during field trips (Arduini, 2012). This social training also provide for the learners who came from different social-cultural background an opportunity of how to behave and control emotion in different situations (Shakil, Faizi \& Hafeez, 2011).

Field trips also benefit Social Studies teachers in addition to students. Field trips bring to the attention of learners the type of activities that generate excitement in their students and can be replicated in the classroom. The new information and knowledge presented during the field trips adds to the lesson plan and helps the teacher to come up with new ideas for instruction. Teachers can also assign work to supplement the field trips to ensure that students understand the lesson (Heath, 2012). In a nutshell field trip brings classroom study alive for students and helps them remember and relate to what they have learned. It provides rich resources that can rarely be approximated in the classroom. Field trip also helps to connect school to the world. It provides new cultural contexts for literature and provokes questions. Field trips stimulate and focus class work by helping students synthesize information.

The researcher has observed that in the recent time, as valuable as field trip is, many Social Studies teachers are no more showing interest in organising field trips for the learners any longer in that a large amount of preparation is associated with planning a field trip. Many are discouraged because they felt the administrative procedures to organise field trip are too burdensome. The worrying of some Social Studies teachers is all about the cost of field trips. The reality is that there are families that can barely afford to send a healthy lunch to school with their children, never mind pay for a field trip. This can be an awkward and uncomfortable situation for both student and teacher (Gray, 2012). On several occasions parents are not in support of field trip in the fear of the risk involve. There are liability risks associated with taking children off school sites. In some cases, students have either been lost by teachers while on a field trip and some students have even died (Greenhalgh, 2012). Collection of consent forms and how to get appropriate-sized buses is normally done by the teacher and adds to the excess workload on the ground (Michie, 1998). Field trips can be stressful for teachers, and one of the reasons is the medical risk. Medical kits must be carried for all with special needs within a classroom, including diabetic students and students with allergies. Also, there must be someone along that is trained to administer medication (Gray, 2012).

The challenges that grow along with the value of field trip have become a serious concern to Social Studies scholars. Many teachers have been forced to forgo field trip due to lack of fund, overload schedules and risk of live involve in field trip. Stoddard (2009) confirms that in the current state of Social Studies education field trips are being cut from many schools' curriculum. Field trip cannot just be ignored or eradicated for all its benefits. Therefore, Social Studies teacher with the use of technology now incorporates virtual field trip. Virtual field trip is a guided and narrated electronic tour that have been selected by educators and arranged in a thread of programmes that students can follow from site to site with just the click of a single button. It is a technology-based experience that allows children to take an educational journey without leaving the classroom (Cox \& Su 2004). The learner have the opportunity to move forward and backward through the field trip using the tour control panel and can leave the tour to explore links and return to it whenever they want. Virtual field trips can be repeated over and over again, this gives learners more room to move at their own pace and explore things to their own depth. In many cases, the places learners would most like to visit may be where they could not go or not nearby. Following these, many teachers believe that the next best thing to a real field trip is a virtual 
field trip in that virtual field trips take learners to places they could not otherwise go. Effort to find out if virtual field trip can be a perfect substitution of real field trip informed this study.

The objectives of the study are to:

a. compare the effectiveness of virtual field trip and real field trip instructional strategies on students' knowledge in Social Studies in Osun State secondary schools and

b. compare the effectiveness of virtual field trip and real field trip instructional strategies on students' retention ability in Social Studies in Osun State secondary schools students.

\section{Research Hypotheses}

From the aforementioned objectives the following are the research hypotheses

Ho1: There is no significant difference in the effectiveness of virtual field trip and real field trip instructional strategies on students' knowledge in Social Studies among Osun State secondary schools students.

Ho2: There is no significant effectiveness of virtual field trip and real field trip instructional strategies on students' retention ability in Social Studies among Osun State secondary schools students.

\section{Theoretical Framework}

This study is based on Ecological constructivists learning theory, a branch of knowledge which describes the nature, methods and limitation of human knowing. Ecological constructivists such as Urie Bronfenbrenner, Sebastian Maslow, Ayako Nakamura and Sola Ehindero believe that the process of knowing and the idea of knowledge are embedded in the different artifacts and components of the ecological environment (Bronfenbrenner, 1990, Ehindero, 2006, Oswalt, 2008, Maslow \& Nakamura, 2008). Central to the principle of ecological constructivism is the belief that individual ecological environment, specific cultural patterns operate to influence one's beliefs and value systems which can define how such individual act, decide, appraise, judge, perceive, think and solve problems. Ecological constructivism is also concerned with the quality of such an environment, the prevailing socio-cultural framework, their systems of language, norms, beliefs and values, structure of the education system, the schools and their curricula as underlying factors influencing how and to what extent learners can build their unique models of making meaning (Ehindero, 2006).

Ecological constructivism believes that there are two sources of knowledge for the learner: The first is the knowledge learners acquire from interaction with the environment. Its primary characteristic is that it constitutes the person's reality, something the person believes in. This is influenced by language, culture, the physical environment and by parents, peers and other people. The second source of knowledge is formal instruction, or school knowledge, which is someone else's interpretation of the world, someone else's reality (Bell, 1993). Ecological constructivists support the use of field trip strategy as emphasized in this study. They believed that education should provide opportunity for the child to learn from different socio-cultural setting and broaden their knowledge and understanding. This is important in order to give room for learners to articulate their personal realities more clearly, discover new useful ideas and reshapes their knowledge. Ecological constructivism has nothing against learning in the school environment because it is another vital way in which the totality of the students can be developed. Nevertheless, school instruction was seen as someone else's interpretation of knowledge to the learners.

\section{Methodology}

The study employed the non-equivalent pre-test, post-test control group design. The sample consist of 127 JSS I students. Two public schools were randomly selected for the study. From each of the two schools, one intact JSS1 class was randomly assigned to either virtual field trip or real field trip group. The two groups were taught the same subject matter using different teaching methods that is virtual field trip and real field trip strategies. Lesson delivery strategies include the use of Video CD Documentary that discusses environmental issues for the virtual field trip group. Students in the real field-trip group were carried out to the community to learn about the environment. One instrument namely Secondary School Students' Environmental Knowledge Test (SEKT) was used to collect data on the knowledge of the students about the environment. The SEKT has two sections, section A has to do with the instruction and personal data of the respondents, section B consisted of a multiple choice test of 20 items.

The study was carried out in five weeks. The first week of the study was used to meet and strategize with the research assistant and co-opted Social Studies teachers of the selected schools. The research instrument was administered on the sample students as the pre-tests. Treatments began in the second week of the study the co-opted 
teachers of the selected schools introduced and taught the sample students same environmental education concepts with different instructional strategies. Each member of the first experimental group (group A) was given electronic package which contain environmental documentary to study for one week after which the content of the package was discussed in the classroom. The teacher of the second experimental group (group B) carried out a field trip with the students in the company of the researcher to relevant places within the community to study the environment. After which the field experience of the students were discussed in the class. At the end of the teaching/learning exercise (i.e. at the beginning of the fifth week) a post-test was administered on the students in the two groups. The scoring was done by the researcher. The maximum score obtainable in the pre-test and post test score of SEKS is 20 marks. Data collected were analysed based on the stated hypotheses using ANCOVA statistics.

\section{Results}

Hypothesis1: Research Hypothesis one states that there is no significant difference in the effectiveness of virtual field trip and real field trip on students' knowledge in Social Studies among Osun State secondary schools students.

The scores of the students in the two groups obtained with the use of SEKT were subjected to analysis of covariance (ANCOVA) to determine whether the hypothesis should be rejected or not. This was tested at 0.05 level of significance. The decision role is such that null hypothesis $\left(\mathrm{H}_{0}\right)$ is rejected if the value of Sig. (2-sided) is less than 0.05 . The essence of this hypothesis is to determine the effectiveness of virtual field trip and real field trip on students' knowledge in Social Studies among Osun State secondary schools students.

Table 1: Statistical Description of Virtual and Real Field Trip Strategies on Students' Environmental Knowledge Test

\begin{tabular}{|l|c|c|c|}
\hline \multicolumn{4}{|c|}{$\begin{array}{c}\text { Descriptive Statistics } \\
\text { Dependent Variable: test }\end{array}$} \\
\hline strategies & Mean & Std. Deviation & $\mathrm{N}$ \\
\hline virtual field trip pre test & 6.0313 & 1.46892 & 64 \\
real field trip pre test & 5.3548 & 2.26952 & 62 \\
virtual field trip post test & 17.9844 & 2.91407 & 64 \\
real field trip post test & 12.3226 & 2.20115 & 62 \\
\hline
\end{tabular}

Table 1 shows the statistical description of the pre and post test results of the two types field trip instructional strategies on students' knowledge with virtual field trip pre-test $\bar{X}=6.0313$, real field trip pre-test $\bar{X}=5.3548$, and virtual field trip post test $\bar{X}=17.9844$, real field trip post test $\bar{X}=12.3226$. To determine if the observed effectiveness is significant at 0.05 level ANCOVA was conducted and the summary of the analysis is presented in table 2.

Table 2: ANCOVA Summary of Virtual and Real Field Trip Strategies on Students' Environmental Knowledge Test

Tests of Between-Subjects Effects

Dependent Variable: test

\begin{tabular}{|l|c|c|c|c|c|}
\hline Source & Type III Sum of Squares & df & Mean Square & F & Sig. \\
\hline Corrected Model & $6709.666^{a}$ & 3 & 2236.555 & 433.108 & .000 \\
Intercept & 27371.484 & 1 & 27371.484 & 5300.476 & .000 \\
strategies & 6709.666 & 3 & 2236.555 & 433.108 & .000 \\
Error & 1280.664 & 248 & 5.164 & & \\
Total & 35501.000 & 252 & & & \\
Corrected Total & 7990.329 & 251 & & & \\
\hline
\end{tabular}

a. $\mathrm{R}$ Squared $=.840$ (Adjusted $\mathrm{R}$ Squared $=.838)$

Table 2 shows that there is a significant difference in the effectiveness of virtual field trip and real field trip on students' knowledge in Social Studies among Osun State secondary schools students with $F=433.108$ at $p<0.05$. The difference is in favour of the virtual field trip. Therefore, this hypothesis is rejected. A post hoc analysis was also conducted to establish the direction of the effect observed so far. 
Table 3: Post Hoc Analysis of Virtual and Real Field Trip Strategies on Students' Environmental Knowledge Test

\begin{tabular}{|c|c|c|c|c|c|c|}
\hline \multicolumn{7}{|l|}{ Multiple Comparisons } \\
\hline \multicolumn{7}{|c|}{ Dependent Variable: test Scheffe } \\
\hline \multirow{2}{*}{ (I) strategies } & \multirow{2}{*}{ (J) strategies } & \multirow{2}{*}{ Mean Difference (I-J) } & \multirow{2}{*}{ Std. Error } & \multirow[b]{2}{*}{ Sig. } & \multicolumn{2}{|c|}{ 95\% Confidence Interval } \\
\hline & & & & & Lower Bound & Upper Bound \\
\hline \multirow{3}{*}{ virtual field trip pre test } & real field trip pre test & .6764 & .40494 & .427 & -.4634 & 1.8162 \\
\hline & virtual field trip post test & $-11.9531^{\star}$ & .40171 & .000 & -13.0839 & -10.8224 \\
\hline & real field trip post test & $-6.2913^{*}$ & .40494 & .000 & -7.4311 & -5.1515 \\
\hline \multirow{3}{*}{ real field trip pre test } & virtual field trip pre test & -.6764 & .40494 & .427 & -1.8162 & .4634 \\
\hline & virtual field trip post test & $-12.6295^{\star}$ & .40494 & .000 & -13.7694 & -11.4897 \\
\hline & real field trip post test & $-6.9677^{*}$ & .40814 & .000 & -8.1166 & -5.8189 \\
\hline \multirow{3}{*}{ virtual field trip post test } & virtual field trip pre test & $11.9531^{*}$ & .40171 & .000 & 10.8224 & 13.0839 \\
\hline & real field trip pre test & $12.6295^{\star}$ & .40494 & .000 & 11.4897 & 13.7694 \\
\hline & real field trip post test & $5.6618^{*}$ & .40494 & .000 & 4.5220 & 6.8016 \\
\hline \multirow{3}{*}{ real field trip post test } & virtual field trip pre test & $6.2913^{*}$ & .40494 & .000 & 5.1515 & 7.4311 \\
\hline & real field trip pre test & $6.9677^{\star}$ & .40814 & .000 & 5.8189 & 8.1166 \\
\hline & virtual field trip post test & $-5.6618^{*}$ & .40494 & .000 & -6.8016 & -4.5220 \\
\hline
\end{tabular}

Table 3 shows that the two strategies are effective in enhancing students knowledge in Social Studies (virtual field trip pretest and virtual field trip post test with $\bar{X}$ difference $=11.9531$, real field trip pre test and real field trip post test with difference $=6.9677$ ). Meanwhile, the difference in the effectiveness observed in the post test of the two groups is in favour of virtual field trip (virtual field trip post test and real field trip post test with $\bar{X}$ difference $=5.6618$ ).

Hypothesis 2: states that there is no significant effectiveness of virtual field trip and real field trip on students' retention ability in Social Studies among Osun State secondary schools students.

The scores of the students in the two groups obtained with the use of SEKT for the post test and retention ability were subjected to analysis of covariance (ANCOVA) to determine whether the hypothesis should be rejected or not. This was tested at 0.05 level of significance. The decision role is such that null hypothesis $\left(\mathrm{H}_{0}\right)$ is rejected if the value of Sig. (2-sided) is less than 0.05 . The essence of this hypothesis is to determine the effectiveness of virtual field trip and real field trip on students' retention ability in Social Studies among Osun State secondary schools.

Table 4: Statistical Description of Virtual and Real Field Trip Strategies on Students' Retention Test

\begin{tabular}{|l|c|c|c|}
\multicolumn{3}{|c|}{ Dependent Variable: test } \\
\hline strategies & Mean & Std. Deviation & $\mathrm{N}$ \\
\hline virtual field trip pre test & 6.0313 & 1.46892 & 64 \\
real field trip pre test & 5.3548 & 2.26952 & 62 \\
virtual field trip post test & 17.9844 & 2.91407 & 64 \\
real field trip post test & 12.3226 & 2.20115 & 62 \\
virtual field trip retention & 18.3621 & 1.87970 & 58 \\
real field trip retention & 18.0351 & 2.22779 & 57 \\
Total & 12.8774 & 6.00944 & 367 \\
\hline
\end{tabular}

Table 4 shows the statistical description of the retention test results for the two types of field trip instructional strategies on students' knowledge with virtual field trip post test $\bar{X}=17.9844$ while retention test $\bar{X}=18.3621$, and real field trip post test $\bar{X}=12.3226$ while retention $\bar{X}=18.0351$. To determine if the observed effectiveness is significant at 0.05 level, ANCOVA was conducted and the summary of the analysis is presented in table 5 . 
Table 5: ANCOVA Summary of Virtual and Real Field Trip Strategies on Students' Retention Test

Tests of Between-Subjects Effects

Dependent Variable: test

\begin{tabular}{|l|c|c|c|c|c|}
\hline Source & Type III Sum of Squares & df & Mean Square & F & Sig. \\
\hline Corrected Model & $11457.492^{\mathrm{a}}$ & 5 & 2291.498 & 470.020 & .000 \\
Intercept & 62039.623 & 1 & 62039.623 & 12725.244 & .000 \\
strategies & 11457.492 & 5 & 2291.498 & 470.020 & .000 \\
Error & 1759.990 & 361 & 4.875 & & \\
Total & 74076.000 & 367 & & & \\
Corrected Total & 13217.482 & 366 & & & \\
\hline
\end{tabular}

a. R Squared $=.867$ (Adjusted R Squared $=.865$ )

From table 5 the result shows that there is a significant effectiveness of virtual field trip and real field trip on students' retention ability in Social Studies among Osun State secondary schools students with $F=470.020$ at $p<0.05$. Therefore hypothesis two is rejected. A post hoc analysis was also conducted to establish the direction of the effectiveness observed as presented in table six.

Table 6: Post Hoc Analysis of Virtual and Real Field Trip Strategies on Students' Retention Test

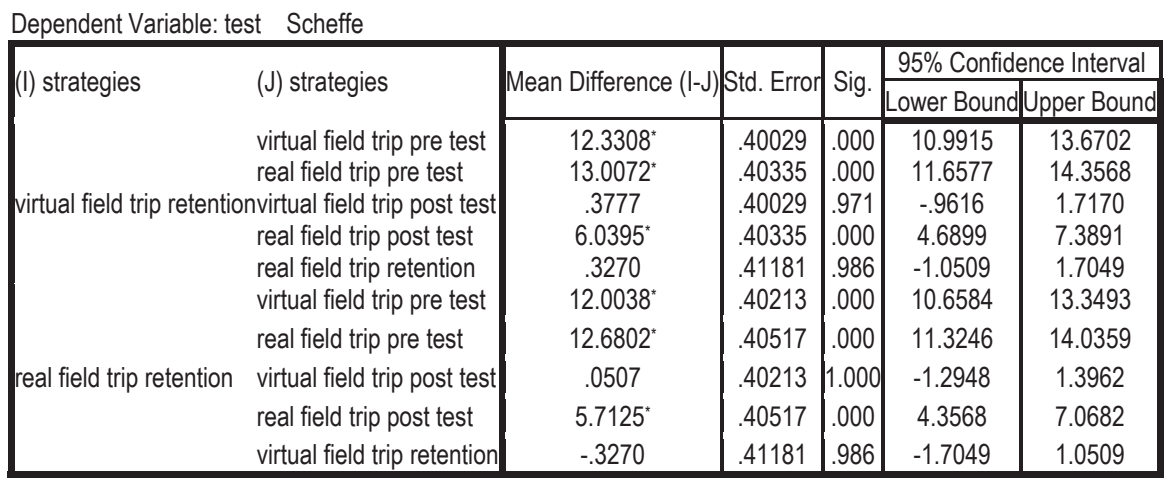

According to table 5 the post hoc comparison of the post test and retention test of virtual field trip showed no significant difference with $p=0.971$. The result of the post test and retention test of real field trip indicated significant difference on the students' retention with $p=0.000$. The result showed that real field trip strategy can help students to retain knowledge better than virtual field trip strategy.

\section{Discussion}

The results of this study showed that both virtual field trip and real field trip are effective strategies in enhancing students' knowledge in Social Studies. Researches have also established that both virtual field trip and real field trip strategies are effective instructional strategies. For instance, findings from the study carried out by Oyler (2014) on 'Does the Use of Virtual Field Trips Increase Vocabulary and Comprehension Scores for Students with Learning Disabilities?' showed that the use of virtual field trips does have a significant impact on student comprehension and vocabulary achievement. In the same vein, Prokop, Tuncer, and Kvasnicak (2007) conducted a one-day real field trip for both improving students' knowledge in ecology. Based on the results of the research conducted three days after the trip, they found a significant and positive increase in students' attitudes toward biology, natural environment outside and future career in biology. However, no similar pattern was observed for the control group.

The results of this study also showed that students in the virtual field trip group manifested significant difference in their performance above the students in the real field trip group. This result contradict the findings of Howell, Turpin, Hunt, and Myers, (2010) on 'Virtual Field Trips: The Good, The Bad, and The Virtual' which showed no statistical difference between the scores generated by the physical field trip group and the virtual field trip group. Also, the investigation of 
Lewis (2008) on 'Can virtual field trip be substituted for real field trip in an eighth grade geology curriculum?' showed that there was no significant difference on the final assessment between the scores of the real-world field trip participants and the scores of the virtual field trip participants. The difference may be due to the difference in the environment and the mode of virtual field trip application. The respondent in the study are not familiar with the use of virtual field trip, introducing virtual field trip as a new instructional strategy may serve as a motivation for them to learn fast. More so the mode of application that provides opportunity for the students to watch the virtual field trip documentary over and over may have helped them to understand better. However, the findings of this study further showed that students in the real field trip developed retention ability better than those in the virtual field trip group. This could be due to the fact that they are able to physically exploit the field site with all their senses.

\section{Conclusion}

This study empirically established that both virtual field trip and real field trip are two types of community contact instructional strategies effective in developing students' knowledge in Social Studies. It was concluded that virtual field trip cannot be a perfect replacement of real field trip because while knowledge acquisition is better with the use of virtual field trip, retention of the acquired knowledge is better with the use of real field trip. However, virtual field trip could be used in conjunction with real field trip to promote effective learning. This opinion is in line with the view of researchers such as Howell, Turpin, Hunt, and Myers, (2010), Robinson (2009) and Kirchen, (2011) as against Cantwell (2004) who belief that virtual field trips strategy may become an adequate alternative to the traditional field trip strategy.

\section{References}

Arduini, J., (2012). The Significance of Field Trips in Education. eHow online article retrieved on 21/01/2013 from http://www.ehow.com labout_5439078_virtual-vs-physical-field-trips.html\#ixzz2lbvuLj2U

Behrendt, M. \& Franklin, T., (2014). A Review of Research on School Field Trips and Their Value in Education International Journal of Environmental \& Science education 9, 235-245

Bell, B., (1993). Children's science: Constructivi.sm and learning in science. Geelong, Victoria: Deakin University Press.

Bronfenbrenner, U., (1990). Discovering what families do. In Rebuilding the Nest: A New Commitment to theAmerican Family. Family Service America [web site]. http://www.montana.edu/www4h/process.html

Cantwell , L. B. (2004). A comparison of learning integration of a virtual and traditional field trip into an introductory environmental geology course. Unpublished M. Sc. Thesis, Montana state university.

Cox, E.S., \& Su, T., (2004). Integrating student learning with practitioner experiences via virtual field trips. Journal of Educational Media $29(2): 113-23$.

Ehindero, O. J., (2006). Environmental education and sustainable development. Lagos: lantern books.

Fuller, S., (2012). The Benefits of Field Trips. eHow online article retrieved on 21/01/2013 from http://www.ehow.com/about_5439078_ virtual-vs-physical-field-trips.html\#ix zz2lbvuLj2U

Gray, S., (2012). The disadvantage of field trip. eHow online article retrieved on 21/01/2013 from http://www.ehow.com/about_5439078 _virtual-vs-physical-field-trips.html\#ixz z2lbvuLj2U

Greenhalgh, N., (2012). Are Field Trips Important to Schools?. eHow online article retrieved on 21/01/2013 from http://www.ehow.com/ about_5439078_virtual-vs-physical-field-trips.html\#ixzz2lbvuLj2U

Heath, D,. (2012). The Significance of Field Trips for Students. eHow online article retrieved on 21/01/2013 from http://www.ehow.com/ about_5439078_virtual-vs-physical-field-trips.html\#ixzz2lbvuLj2U

Howell, A., Turpin, A., Hunt, C. \& Myers, C., (2010) Virtual Field Trips: The Good, The Bad, and The Virtual. J Hum Ecol, 31(3): 171-177.

Kirchen, D. J., (2011). Making and taking virtual field trips in Pre-K and the Primary Grades. The National Association for the Education of Young Children. www.naeyc.org/yc/permissions

Krepel, W. J., \& Durral, C. R., (1981). Field trips: A guideline for planning and conducting educational experiences. Washington, DC: National Science Teachers Association.

Lewis, D. B., (2008). Can virtual field trip be substituted for real field trip in an eighth grade geology curriculum? University of Washington.

Maslow, S. \& Nakamura, A., (2008). Constructivism and Ecological Thought: A Critical Discussion on the Prospects for a 'Greening' of IR Theory. Interdisciplinary Information Sciences, Vol. 14, No. 2, pp. 133-144.

Michie, M., (1998). Factors influencing secondary science teachers to organise and conduct field trips. Australian Science Teacher's Journal, 44(4), 43-50.

Nabors, M.L., Edwards, L.C., \& Murray, R. K., (2009). Making the case for field trips:What research tells us and what site coordinators have to say. Education 129(4), 661-667.

Oblinger, D. G., (2006). Learning Space. EDUCAUSE. Retrieved on 09/05/15 from www.educause.edu/learningspaces.

Oloyede, E. O., Ajibade, Y. A. \& Bamidele, E. F., (2006). Choice and effective use of teaching methods. In Ehindero, O J. Dibu-ojerinde, O.O.and Ajibade, Y. A. Curriculum and the teaching process. Ghana, Dama Educational Services Ltd. 
Oswalt, A., (2008). Urie Bronfenbrenner And Child Development. https://www.mentalhelp.net/articles/urie-bronfenbrenner-and-childdevelopment/

Oyler, M., (2014). Does the use of virtual field trips increase vocabulary and comprehension scores for students with learning disabilities? Northwest Missouri State University Missouri.

Prokop, P., Tuncer, G. \& Kvasnic, R., (2007). Short-Term effects of field programme on students' knowledge and attitude toward biology: a Slovak experience. Journal of Science Education and Technology, Vol. 16, No. 3, June 2007.

Robinson, L., (2009). Virtual Field Trips: The pros and cons of an educational innovation. Computers in New Zealand Schools: Learning, Teaching, Technology, 21(1).

Shakil, A. F., Faizi, W. \& Hafeez, S., (2011). The need and importance of field trip at higher level in Karachi, Pakistan. International Journal of Academic Research in Business and Social Sciences Vol. 2 No. 1.

Stoddard, J., (2009). Toward a virtual field trip model for the social studies. Contemporary Issues in Technology and Teacher Education, $9(4), 412-438$.

Tal, T., \& Morag, O., (2009). Reflective practice as a means for preparing to teach outdoors in an ecological garden. Journal of Science Teacher Education, 20(3), 245-262. 